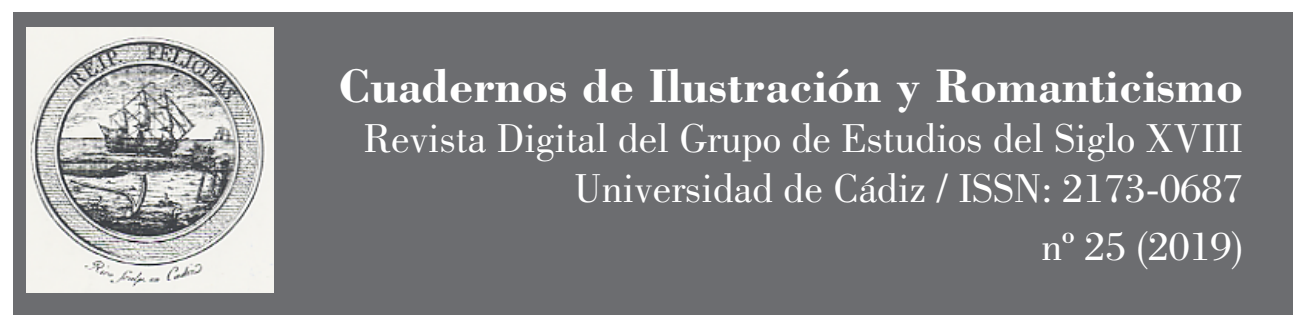

\title{
BLANCO WHITE AND THE «UNFORTUNATE SPANIARDS»
}

\author{
Martin MuRPHY \\ (Royal Historical Society)
}

Recibido: 17-11-2019/Revisado: 17-11-2019

Aceptado: 17-11-2019/ Publicado: 20-12-2019

Resumen: José María Blanco White used his social connections in London for the benefit of less fortunate compatriots, afrancesados as well as liberales, by obtaining subsistence grants for them from the Royal Literary Fund, a charity founded for the relief of writers in need, of which his close friend James Christie was Registrar.

Palabras Clave: Blanco White, Royal Literary Fund Society, Reinoso, Lagasca, Moratín, Llorente.

\section{BLANCO WHITE Y LOS «DESDICHADOS ESPAÑOLES»}

ABstRACT: José María Blanco White empleó sus contactos sociales en Londres en beneficio de sus compatriotas menos afortunados, tanto afrancesados como liberales, obteniendo subsidios para ellos del Royal Literary Fund, institución caritativa fundada para el socorro de escritores necesitados, de la cual su íntimo amigo James Christie era Secretario.

Keywords: Blanco White, Royal Literary Fund Society, Reinoso, Lagasca, Moratín, Llorente. 
The Royal Literary Fund Society of London, founded in I790, was the product of an age of philanthropy. Its object was «to administer assistance to authors of merit and good character who may be reduced to distress by unavoidable calamities, or deprived by enfeebled faculties or declining life of the power of literary exertion». Recipients did not necessarily have to be British: as a young man, in $\mathrm{I}_{799}$, Chateaubriand received a grant of ten guineas when he was a poverty-stricken exile in London. Twenty-three years later, in 1822 , he returned to London as French ambassador and was the guest of honour at the Society's annual banquet —one of the most fashionable events of the London social calendar.

One of the most active members of the Society (and its Registrar from I824 to I83I) was the wealthy art dealer and auctioneer James Christie. He befriended Blanco White soon after his arrival in London in I8ro, welcomed him into his home and introduced him to society. Christie's standing as a member of the Literary Fund Committee enabled Blanco to come to the assistance of his less fortunate compatriots, both afrancesados and liberales. On his recommendation grants were made in 1822 to Leandro Fernández de Moratín and Juan Antonio Llorente, in 1825 to Félix José Reinoso, and in 1826 to the botanist Mariano La Gasca. ${ }^{\top}$ The grateful acknowledgements sent to Blanco by Moratín and Llorente were the subject of an article by Vicente Llorens (1967), but Blanco's letters of recommendation, kept in the Literary Fund archives (now in the British Library) are published here for the first time.

Blanco White, 7 Paradise Row, Chelsea, 26 September I822. ${ }^{2}$

My dear Christie,

We have often talked of Moratín and Llorente, two eminent literary characters among my countrymen, whom the political storms of Spain have driven from places of honour and emolument to a life of poverty and exile in France. You then gave me hopes that if I could learn their places of residence, something perhaps could be done to relieve their sufferings by laying their case before the committee of the Literary Fund Society. I have lately succeeded in my search and herewith you will find their respective addresses. I must however refresh your memory in regard to the circumstances of my unfortunate compatriots, as far as they are known to me.

Moratín is the author of six plays which Spaniards of all parties are proud to place at the head of the specimens of national genius which the long reign of the Inquisition has not been able to stifle. If Moratín does not equal Molière in originality and boldness of conception he is certainly not inferior to the French poet in delineation of character, in the ingenious arrangement of the plot, and in the spirit and truth of the dialogue. Though Moratín's comic humour is highly national, and likely to be lost in translation, there is a tone of feeling throughout his plays which like that of his favourite model, Terence, must reach the human heart in all ages and countries. In one circumstance, however, and that of no slight importance to the best interests of mankind, my countryman stands unrivalled — the perfect delicacy and purity of his Muse. I have seen large audiences convulsed

I A further application on behalf of Álvaro Agustín de Liaño, «Librarian to the King of Prussia», was rejected on the grounds that the Society should not identify itself with authors «merely political». See Martin Murphy (2002).

2 Royal Literary Fund no. 474, vol. I3. 
with laughter during the performances of Moratín's plays, without his ever stooping to amuse one part of the house at the expense of the blushes of the other.

Llorente's chief department of knowledge is the history and laws of his country. It will be enough to mention his History of the Spanish Inquisition, which in a French translation has lately found its way to this country. It is a cool, impartial and authentic record of the proceedings whereby that abominable tribunal has for more than three centuries stunted the mental energies of the Spaniards. $\mathrm{Mr}$ Llorente, the author, was among the first dignitaries of the Church of Spain, to which, notwithstanding the temptations of a corrupt court where his talents and learning had obtained him a considerable degree of favour and influence, he was an ornament by the correctness and decorum of his manners.

I have often told you, and you may pledge my words to your friends upon the fact, that not all the honest, worthy and enlightened men of Spain were on the side of the patriots. The usurpation of Joseph Bonaparte took place without the concurrence of a single Spaniard. When, however, the members of the royal family were removed and either induced or forced to resign their claims, many a truly loyal subject conceived the contest with France to be hopeless, and submitted to the new dynasty. Moratín and Llorente were too well known for their talents not to be included in the list of promotions by which the government under Joseph were anxious to evince their determination of rewarding merit of all kinds in the natives. In the discharge of their public duties these two gentlemen, no less than many other excellent Spaniards who were placed in similar circumstances, exerted themselves in favour of their countrymen, and actually saved the lives of a great number who would otherwise have fallen under the French sword. Yet a narrow and interested policy has induced both the Cortes and Ferdinand VII to punish every Spaniard who held a place under Joseph with the confiscation of their property.

Without the benefit of a trial, and overwhelmed by the consequences of this sweeping sentence, the two distinguished Spaniards whom I recommend to your notice are languishing in France where their talents, from the difference of language, can avail them but little. Both are, besides, on the verge of old age, when the change from their former affluence to their present state of indigence will be most keenly felt. I wish only to add that my application in their favour is perfectly unsolicited.

Believe me, my dear Christie, ever affectionately yours,

J. Blanco White.

Writing from Paris on I2 December, Llorente replied:

A los señores Presidente y Miembros de la Junta del Literary Fund Society de Londres.

Señores,

Por dirección de mi compatriota el señor don Juan [sic] Blanco Whuite [sic] he recibido quinientos francos, o veinte livras esterlinas, que la generosidad y la caridad de tan benéfica sociedad ha querido destinar en mi favor. Esta suma, que siempre hubiera sido estimable para todo hombre de letras, con quien parece hallarse en guerra la riqueza desde tiempos antiguos, lo ha sido más en la ocasión en que el Ministro del Interior de este reyno me acaba de mandar salir de Francia en el termino preciso para llegar a la frontera de España, por haber publicado la 
Historia crítica de la Inquisición y el Retrato político de los Papas, cuyo Nuncio ha satisfecho su pasión y venganza pidiendo mi destierro sin preceder juicio alguno ni oirme. Doy, pues, las gracias mas sinceras a la Sociedad y a su Junta por muchos beneficios que me ha hecho con un [?] solo, y apetezco ocasiones de manifestar mi reconocimiento en Madrid a donde parto sin voluntad y solo por necesidad.

Entretanto y siempre pediré a Dios que se digne conceder toda felicidad a la Sociedad y a sus individuos, de quienes seré toda mi vida reconocido servidor,

Juan Antonio Llorente

Don Felix-Josef Reynoso, formerly Prebendary of the Cathedral of Seville, and Professor of Belles-Lettres in the University of Seville. ${ }^{3}$

\section{Gentlemen,}

The great kindness with which, some time ago, you answered an application of mine in favour of two of my countrymen, as it has left upon me an indelible impression of gratitude, so it would have bound me, in delicacy, to abstain from troubling you again, had not a case presented itself which forces me to disregard that feeling.

Don Félix-José Reynoso, now resident in Xerez, is a Spanish clergyman whom I knew as a fellow-student at the University of Seville, and with whom I lived in the habits of daily intercourse till in I8ro I quitted my country. His talents and excellent character recommended him to the Chapter of the Cathedral of that town, whose members, in consequence of a public examination where Reynoso distinguished himself, appointed him to the incumbency of one of the parish churches of Seville. Untainted with the sceptical opinions which blight the early promise of usefulness among the ablest of the Spanish clergy, my friend discharged his duties for some years with the most exemplary zeal. During a contagious fever, aggravated by a scarcity approaching to famine which raged at Seville in the year I8I2 or I8I3 (I am not certain) my friend fearlessly exposed his life for the relief of the suffering poor, and laboured night and day to carry food and consolation to their dwellings.

It was soon after this calamity that Joseph Buonaparte visited Seville, in hopes of gaining the affections of the Andalucians by a display of liberality in the acts of his government. Though Reynoso never approached the usurper, such however was the esteem in which he was held by the public that, a prebendal stall becoming vacant, the intrusive King believed he could not recommend himself more effectually to the people than by appointing to it the most respected ecclesiastic in the town. Reynoso had enjoyed his well merited honours but a few months when the retreat of the French armies put the Cortes and the Liberals in possession of Andalusia. An indiscriminate deprivation and ejection of all persons who had been appointed to places of emolument by Joseph Buonaparte was among the first measures of the patriotic government. Reynoso was not only deposed from the dignity to which his merits alone had raised him, but left even without a compensation for the Vicarage which he had resigned upon taking the Prebend.

Without a patrimony of his own, and thus stript of all preferment, his friends procured him the appointment to a chair of Belles-Lettres which had been established 
a short time before at Seville, with the small salary of fifty pounds a year. Thus he lived in poverty for some time till, at the revolution which restored the Cortes in 1820 , he obtained, unsolicited, a nomination to be Secretary to the Provincial Delegation to the Cortes at Cádiz. Reynoso's political opinions, however, were too just and moderate to chime in with the fierce, levelling spirit which prevails in that town. He was consequently assailed by the Demagogues, and it was with difficulty that, on one occasion, he saved himself from the hands of the republican mob. On the restoration of the Absolute Government, my friend, equally unwilling to join the Liberals in their wild schemes of freedom, and the bigots in their plans of oppression, was forced to retire to the town of Xerez, where he lives in penury on the small contributions of a few friends whose means have been greatly limited by the late troubles.

The enclosed Poem*, one of the finest productions of Spanish genius in our times, was written by Reynoso when he had just finished his studies at the University. A work in which he laid down the duties of citizens under the government of an usurper, combines profound learning, acute reasonings and brilliant eloquence in a high degree. Such is the man for whom I implore your benevolence. I will leave the simple story of his lot to plead for him.

I am, Gentlemen, your obedient and much obliged servant, Joseph Blanco White.

* La inocencia perdida. Poema en dos actos premiado en competencia por una Academia de Letras Humanas de Sevilla en Junta Pública de 8 de diciembre de I799.

In a letter to the Committee of the Royal Literary Fund, dated I2 August I825, Blanco enclosed Reinoso's acknowledgement of their grant of $£ 20$, adding that «gentlemen will be pleased to know that assistance arrived at a most seasonable moment and the object of their benevolence has thereby been enabled to settle again in his native town, where Providence seems to open to him a fairer prospect for the future».

The following year Blanco wrote to the Treasurer of the Literary Fund with a further appeal on behalf of the distinguished botanist Mariano La Gasca, Director of the Jardín Botánico of Madrid from I8I6 to I823. In June I823, when he was about to leave Seville for Cádiz La Gasca's entire collection of books, manuscripts and specimens was destroyed by a hostile mob. In the words of his biographer:

Son bien sabidos los horrorosos sucesos del dia I3 de junio de I823 en Sevilla: un populacho desenfrenado y atizado por el fanatismo religioso y político arrojó a las llamas o sumerjió en el río los equipajes de los diputados y empleados que se dirijían precipitadamente a Cádiz como el último baluarte constitucional. Entre estos equipajes se hallaba el de La Gasca: casi toda su biblioteca y herbario: perdióse sin recurso un tesoro de la ciencia, perdiéronse los materiales de la gran obra, fruto de 30 años de trabajos y observaciones (Yáñez, I842: 4I-42).

With no immediate means of supporting his family or continuing his scientific work, he had recourse to Pablo Mendíbil, who took his case to Blanco: 
${ }_{27}$ Hunter Street, Brunswick Square, 7 August $1826^{4}$

Mi muy estimado Amigo y Señor,

Conozco y trato mucho a Don Mariano Lagasca y a su familia compuesta de su muger, dos hijos ya mozos y otros dos menores de 8 años, con quienes se halla emigrado en esta ciudad. Sé que está muy necesitado, y que es un hombre tan apreciable por su honradez como por su ciencia como botánico. No dudo que un socorro pensionario, por pequeño que sea, le desahogará mucho en la situación en que se halla. Varias vezes le he oido suspirar por algun medio de poder utilizar sus conocimientos aunque fuese disecando flores y plantas para ponerlos en cuadros de mero adorno, y creo que en el dia está ocupándose en algo de esto, llegando a tal extremo su necesidad que ha pedido a otro refugiado un par de libras para comprar papel de estraza y otras frioleras que le hacen falta para trabajar. Mucho me alegraría de cualquier alivio que pudiese tener este infeliz y estimable profesor.

Blanco duly wrote the same day to the Treasurer of the Royal Literary Fund:

7 Paradise Row, 7 August 1826

To Jos Snow Esq.

I enclose a letter from a most respectable Spaniard intimately acquainted with Don Mariano La Gasca. Its contents are most affecting. La Gasca has his wife and four children to support. His distress is so great that he has been obliged to borrow two sovereigns for the purpose of producing some brown paper on which to glue some specimens of plants which he hopes to make a few shillings by. As a botanist $\mathrm{Mr} \mathrm{La} \mathrm{Gasca} \mathrm{is} \mathrm{considered} \mathrm{among} \mathrm{the} \mathrm{most} \mathrm{distinguished} \mathrm{writers} \mathrm{and} \mathrm{professors}$ of that science. I believe he has published some works on medical subjects. My friend assures me that the smallest donation would be gratefully received. I hope my friend Christie will exert himself in favour of this distressed individual and his poor family.

Three days later Mendíbil wrote to Blanco again with further information to be passed on in support of La Gasca's case:

\section{Estimado Amigo y Señor mio,}

Entre varias obras que ha publicado Don Mariano Lagasca solo recuerdo en este momento las siguientes: «Genera et species plantarum quae aut novae sunt aut nondum recte cognoscuntur» Matriti: ex tipographia regia, anno MDCCCXVI; «La Flora Española» de la cual ha copiado muchos trozos el botánico Decandolle; «Amenidades naturales de las Españas» de que publicó varios cuadernos en Madrid desde el año 20 o 2I; y en el tomo 4 de los Ocios se insertaron en varios números sus «Observaciones sobre las umbellíferas y aparasoladas».

Deseo a V. buena salud y que se explaye en Oxford, quedando yo como siempre su affmo amigo, 


\section{Pablo Mendíbil}

P.D. Tambien trabajó y puso algunas notas mui buenas en la edición ultima que se hizo de la Agricultura de Herrera.

La Gasca was very soon welcomed into the scientific community in London, was made a member of the Linnaean Society and granted access to the Chelsea Physic Garden where he was able to continue his researches. In an article «Sketches of the botanical, horticultural, agronomical and rural of Spain», published in The Gardener's Magazine of July I826, he wrote with pride and nostalgia of his lost Eden: the Jardín Botánico of Madrid (Llorens, 1967: 350).

\section{WORKS CITED}

Llorens, Vicente (1967), «Moratín, Llorente y Blanco White», in Literatura, Historia, Politica, Ediciones Revista de Occidente, Madrid, pp. 57-73.

— (I979), Liberales y románticos. Una emigración española en Inglaterra (1823-I834), Castalia, Madrid.

Murphy, Martin (2002), "Álvaro Agustín de Liaño, Chevalier errant», Trienio. Ilustración y liberalismo, 40 (november), pp. I75-190.

Yáñez, Agustín (1842), Elojio histórico de Don Mariano La Gasca y Segura, Barcelona. 